\title{
Terahertz field induced electromigration
}

Strikwerda, Andrew; Zalkovskij, Maksim; Iwaszczuk, Krzysztof; Jepsen, Peter Uhd

Publication date:

2014

Document Version

Publisher's PDF, also known as Version of record

Link back to DTU Orbit

Citation (APA):

Strikwerda, A., Zalkovskij, M., Iwaszczuk, K., \& Jepsen, P. U. (2014). Terahertz field induced electromigration. Abstract from 39th International Conference on Infrared, Millimeter, and Terahertz Waves, Tucson, AZ, United States.

\section{General rights}

Copyright and moral rights for the publications made accessible in the public portal are retained by the authors and/or other copyright owners and it is a condition of accessing publications that users recognise and abide by the legal requirements associated with these rights.

- Users may download and print one copy of any publication from the public portal for the purpose of private study or research.

- You may not further distribute the material or use it for any profit-making activity or commercial gain

- You may freely distribute the URL identifying the publication in the public portal

If you believe that this document breaches copyright please contact us providing details, and we will remove access to the work immediately and investigate your claim 


\title{
Terahertz Field Induced Electromigration
}

\author{
Andrew C. Strikwerda ${ }^{1}$, Maksim Zalkovskij ${ }^{1}$, Krzysztof Iwaszczuk $^{1}$, and Peter Uhd Jepsen ${ }^{1}$ \\ ${ }^{1}$ Technical University of Denmark, DK-2800, Kgs. Lyngby, Denmark
}

\begin{abstract}
We report the first observation of THz-field-induced electromigration in sub-wavelength metallic gap structures after exposure to intense single-cycle, sub-picosecond electric field transients of amplitude up to $400 \mathrm{kV} / \mathrm{cm}$.
\end{abstract}

\section{INTRODUCTION}

$\mathrm{W}$ HEN a metal carries a sufficiently strong electric current, collisions transfer momentum from the conduction electrons to the atomic lattice. This momentum transfer, often referred to as an "electron wind," competes against the direct force of the applied electric field on the lattice atoms. The interplay of these two forces causes the shape of the metal to slowly deform, or migrate, due to the intense applied electric field [1]. This short description is the essence of electromigration. While this phenomenon has been studied extensively at lower frequencies due to its role in the failure of integrated circuits there are, to the best of our knowledge, no reports of electromigration at terahertz $(\mathrm{THz})$ frequencies.

We have observed substantial $\mathrm{THz}$ induced damage, which we attribute to electromigration, in sub-wavelength metallic structures as shown in Figure 1. Our investigation indicates that the damage shown is metal deformation that forms a conducting bridge between the two structures.

\section{SAMPLE FABRICATION}

The samples are 200nm thick gold antennas patterned on a thick high-resistivity silicon (HR-Si) wafer using standard UV photolithography. There are two dipole antennas per unit cell. The two antennas are each $80.9 \mu \mathrm{m}$ long and $5 \mu \mathrm{m}$ wide, and are aligned end to end with a small gap region between them. Samples with gaps of $1,5,7.5$, and $10 \mu \mathrm{m}$ are presented here, and the damage pattern shown in Figure 1 is for a $1 \mu \mathrm{m}$ gap. The unit cell size is $141 \mu \mathrm{m}$ by $282 \mu \mathrm{m}$. This antenna pattern is then arrayed in two dimensions over the HR-Si wafer and has a transmission resonance at $0.6 \mathrm{THz}$. At this frequency the incident electric field is strongly enhanced near the antenna tips, with an even larger enhancement in the gap region between the two antennas [2]. In Figure 1 (c), we overlay a computer simulation of the electric field pattern at the $0.6 \mathrm{THz}$ resonance, clearly indicating that the observed damage closely follows the direction of the electric field.

\section{RESULTS}

The fabricated samples were exposed to incident $\mathrm{THz}$ electric fields of up to $400 \mathrm{kV} / \mathrm{cm}$. Taking into account the simulated field enhancement factor of the antenna structure, the electric field in the center of the gap was estimated to $>2$ $\mathrm{MV} / \mathrm{cm}$ for all samples, with the smaller gap samples having even higher field strengths [2]. The samples were measured continuously using $\mathrm{THz}$ time domain spectroscopy for approximately one hour, and Figure 2 shows the transmission

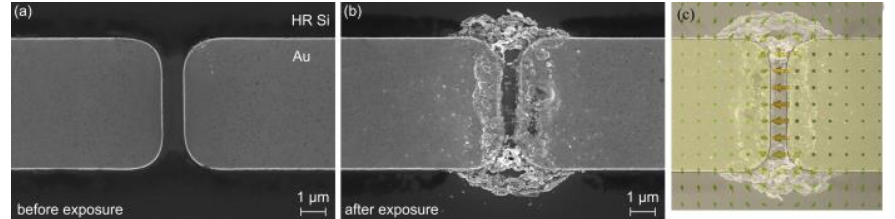

Fig. 1. Scanning electron microscope pictures of the $\mathrm{THz}$ induced damage. (a) and (b) show the gap between the antennas before and after $\mathrm{THz}$ exposure, respectively. (c) The simulated electrical field overlaid with the experimental damage.

response at 0.333 and $0.608 \mathrm{THz}$ as a function of exposure time. These figures are normalized to the transmission at time $=0$, and show the relative decrease (increase) of the transmission at $0.333 \mathrm{THz}(0.608 \mathrm{THz})$, respectively. This suggests that the antenna gap is shorting out and the structure is behaving as a single antenna of twice the length, instead of two coupled antennas. This behavior is consistent with computer simulations of a variable resistance in the gap region (not shown).
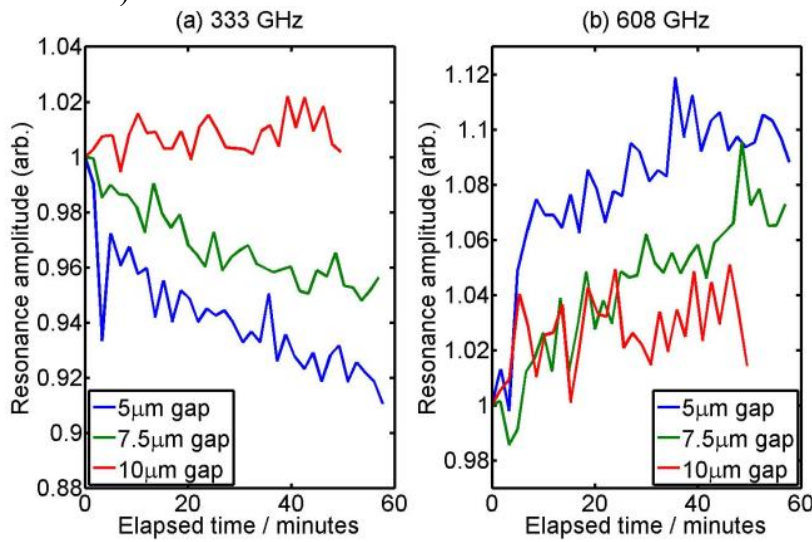

Fig. 2. The experimental change in transmission as a function of time suggests that a conduction path is being formed between the two antennas.

\section{CONCLUSION}

In conclusion, we have made the first observation of $\mathrm{THz}$ field induced electromigration. We anticipate these results to have a significant impact on designing and interpreting $\mathrm{THz}$ studies combining strong electric fields with metallic structures. As switching times in modern nanotransistors approach the $\mathrm{THz}$ regime, our results could represent an important stepping stone towards a new method for testing both short- and long-term damage to ultrafast electronics due to the electric fields in the transistors during operation.

\section{REFERENCES}

[1]. C. M. Tan and A. Roy, "Electromigration in ULSI interconnects," Mater. Sci. Eng. R Reports, vol. 58, no. 1-2, pp. 1-75, Oct. 2007.

[2]. C. A. Werley, K. Fan, A. C. Strikwerda, S. M. Teo, X. Zhang, R. D. Averitt, and K. A. Nelson, "Time-resolved imaging of near-fields in $\mathrm{THz}$ antennas and direct quantitative measurement of field enhancements," Opt. Express, vol. 20, no. 8, p. 8551, Mar. 2012. 